\title{
Design of the subsurface observatory at Surtsey volcano, Iceland
}

\author{
Andreas Türke ${ }^{1}$, Marie D. Jackson ${ }^{2}$, Wolfgang Bach ${ }^{1}$, Wolf-Achim Kahl ${ }^{1}$, Brian Grzybowski ${ }^{3}$, \\ Beau Marshall ${ }^{4}$, Magnús T. Gudmundsson ${ }^{5}$, and Steffen Leth Jørgensen ${ }^{6}$ \\ ${ }^{1}$ Department of Geosciences and MARUM, University of Bremen, Bremen 28357, Germany \\ ${ }^{2}$ Department of Geology and Geophysics, University of Utah, Salt Lake City, Utah 84102, USA \\ ${ }^{3}$ L3 Technologies Inc., Communications and Networked Systems, Salt Lake City, Utah 84116, USA \\ ${ }^{4}$ DOSECC Exploration Services, Salt Lake City, Utah 84101, USA \\ ${ }^{5}$ Nordvulk, Institute of Earth Sciences, University of Iceland, Reykjavík, Iceland \\ ${ }^{6}$ K.G. Jebsen Centre for Deep Sea Research, Department of Earth Science, \\ University of Bergen, Bergen, Norway
}

Correspondence: Steffen Leth Jørgensen (steffen.jorgensen@bio.uib.no)

Received: 26 November 2018 - Revised: 29 April 2019 - Accepted: 3 May 2019 - Published: 12 June 2019

\begin{abstract}
Surtsey, the youngest of the islands of Vestmannaeyjar, is an oceanic volcano created by explosive basaltic eruptions during 1963-1967 off the southern coast of Iceland. The subsurface deposits of the volcano were first sampled by a cored borehole in 1979. In summer 2017, three cored boreholes were drilled through the active hydrothermal system of the volcano by the International Continental Scientific Drilling Program (ICDP) SUSTAIN Expedition 5059. These cores are expected to provide the first glimpse of microbial life in very young and native basaltic tuff of the oceanic crust. To reduce the contamination of the subsurface environment, seawater circulating fluid was filtered and passed through two UV-sterilizing treatments. One of the boreholes has been equipped with a subsurface observatory dedicated in situ experiments for monitoring water-rock interactions and microbial processes in sterile, artificial basaltic glass and in olivine granules. With temperatures ranging from 25 to $125^{\circ} \mathrm{C}$, the subsurface observatory provides a precise geothermal window into an active hydrothermal system and thus represents an exceptional natural laboratory for studying fluid-rock-microbe interactions at different temperature regimes and facilitates experimental validation of active submarine microbial processes at the limit of functional life, about $121^{\circ} \mathrm{C}$. Comparisons with the 1979 and 2019 drill cores will provide time-lapse observations of hydrothermal processes over a 50-year timescale. Here, we present the technical design of the observatory and the incubation chamber experiments deployed from September 2017 to summer 2019.
\end{abstract}

\section{Introduction}

Surtsey volcano forms the southernmost expression of Vestmannaeyjar, an oceanic archipelago created by basaltic eruptions in the offshore extension of the eastern Icelandic rift zone (Jakobsson et al., 2009). Explosive eruptions, followed by effusive lava flows from 1963-1967, constructed the island from a seafloor depth of about $130 \mathrm{~m}$ (Thors and Jakobsson, 1982; Fig. 1a). A cored borehole achieved in 1979 traversed hydrothermally altered basaltic tephra, tuff and intrusions to $181 \mathrm{~m}$ below the surface (mb.s.) but did not reach the pre-eruption seafloor (Jakobsson and Moore, 1982,
1986). Borehole temperatures varied from 25 to $141^{\circ} \mathrm{C}$ in 1980. Investigations of $16 \mathrm{~S}$ rRNA gene amplicons from fluids sampled in 2009 from the 1979 borehole (SE-01) identified microbial communities dominated by Archaea, primarily thermotolerant Methanobacteria at $172 \mathrm{~m}$. b.s. $\left(54^{\circ} \mathrm{C}\right)$ and by thermophilic Archaeoglobus-related sequences at 145 m.b.s. $\left(80^{\circ} \mathrm{C}\right.$; Marteinsson et al., 2015). In summer 2017, the International Continental Scientific Drilling Program (ICDP) 5059 expedition, the Surtsey Underwater volcanic System for Thermophiles, Alteration processes and INnovative Con- 


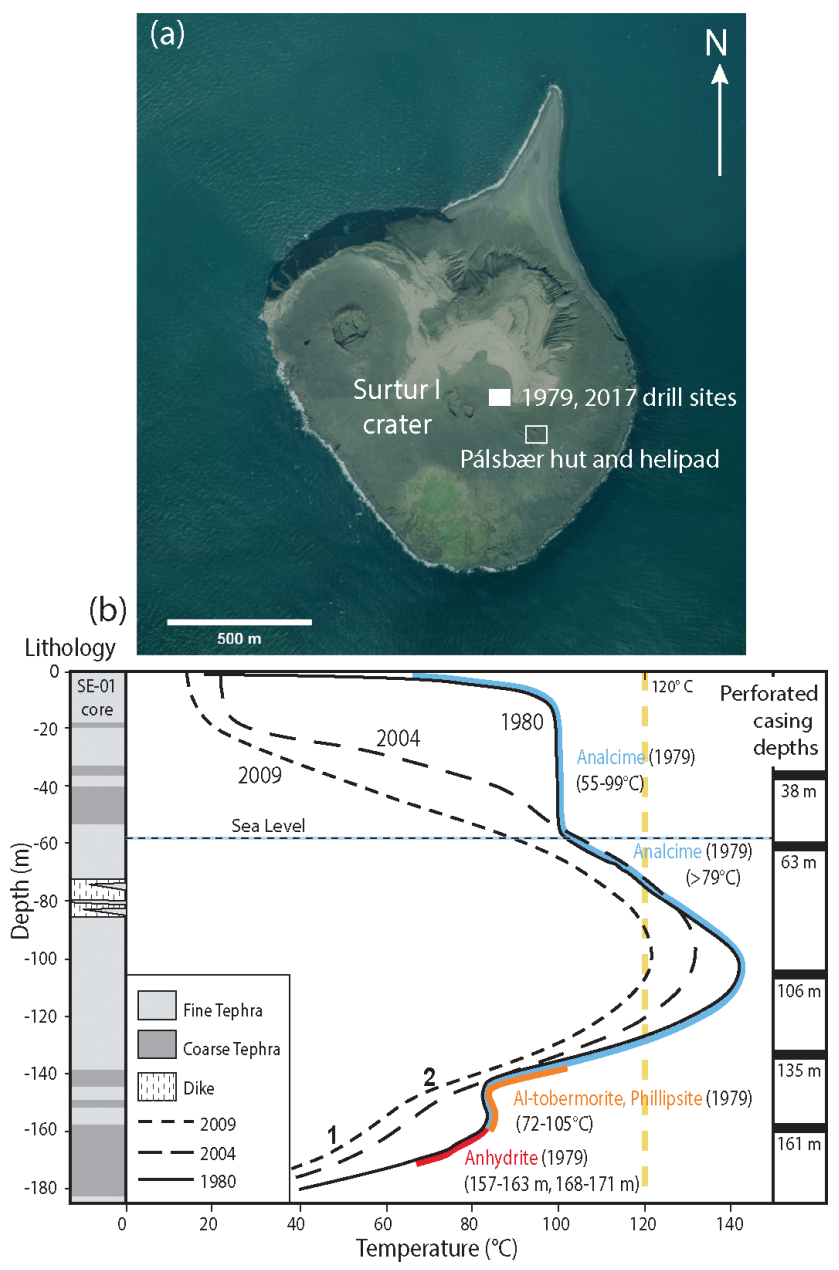

Figure 1. Setting of the Surtsey subsurface observatory in the 50591-C (SE-02b) cored borehole (latitude $63^{\circ} 18.09739^{\prime} \mathrm{N}$, longitude $20^{\circ} 35.99020^{\prime} \mathrm{W}$ ). (a) Aerial photograph of Surtsey, 26 July 2016 (courtesy of Loftmyndir ehf.); (b) temperature profile of the 1979 SE-01 cored borehole (after Jakobsson and Moore, 1986; Jackson et al., 2015) showing the 2009 site 1 and site 2 microbial communities (Marteinsson et al., 2015) and depths of the perforated casing segments. The yellow dashed line indicates the upper limit for functional microbial life, at about $121^{\circ} \mathrm{C}$.

cretes (SUSTAIN), recovered nearly $700 \mathrm{~m}$ of drill core from the basaltic deposits (Jackson et al., 2015, 2019).

While microbial life has been detected in native subsurface oceanic basalts (e.g. Lysnes et al., 2004; Lever et al., 2013; Jørgensen and Zhao, 2016), little is known about the factors that control habitability and the actual extent of the deep crustal biosphere, in terms of cellular mass and spatial distribution (Baquiran et al., 2016). Even less is known about microbial functions and their potential significance in this environment. Energy sources thought to sustain this biosphere could be provided through both chemical and physical processes occurring when volcanic rocks, which make up the majority of the hydrologically active oceanic crust, in- teract with seawater (Bach, 2016). Most observations of the deep biosphere hosted in basalt stem from subsurface observatories deployed at submarine drill holes (e.g. Orcutt et al., 2011; Edwards et al., 2012; Baquiran et al., 2016). While these observations have provided fundamental new knowledge, they focus on oceanic basalts several million years in age, and their accessibility is limited by costly oceanic expeditions, in situ technologies and long travel times.

The Surtsey subsurface observatory, by contrast, provides relatively straightforward access to an exceptionally young and pristine environment that records the initiation of subsurface microbial life in basaltic tephra in a broad range of temperatures, $25-125^{\circ} \mathrm{C}$, measured in the parallel 1979 (SE-01) borehole in 2017 (Fig. 1b), and varying hydrothermal fluid compositions (Jackson et al., 2019). The island is a protected UNESCO World Heritage Site that contains a unique scientific record of colonization of new land by plants, animals and marine organisms through long-term studies of primary biological succession (Baldursson and Ingadóttir, 2007). The time-lapse drill cores obtained in 1979 and 2017 and their associated fluids provide a first glimpse of subsurface marine microbial life in oceanic basalt. The steep temperature gradients in the young hydrothermal system - including a section that in 1979 exceeded the known temperature limit of life, $121^{\circ} \mathrm{C}$ (Fig. 1b; Takai et al., 2008) - offer a unique opportunity to assess temperature dependency of microbial activity in the deep biosphere hosted by oceanic basalt.

\section{Surtsey subsurface observatory design}

The 5059-1-C (SE-02b) borehole began with rotary drilling for a steel HWT conductor casing with an outer diameter (OD) of $11.43 \mathrm{~cm} \mathrm{(4} \mathrm{1/2} \mathrm{in.)} \mathrm{that} \mathrm{extends} \mathrm{to} \mathrm{a} \mathrm{casing} \mathrm{shoe}$ depth of 9.54 m.b.s. (Fig. 2a). The core was then drilled with a HQ3 bit ( $63.5 \mathrm{~mm}$ core diameter) to $191.64 \mathrm{~m}$ vertical depth from 18 to 26 August 2017 using seawater as the circulating fluid. To reduce contamination from live microbes, the seawater was passed through a $30 \mu \mathrm{m}$ cartridge filter to remove fine debris and a WEDECO AQUA 4ALT UV light sterilization system at a flow rate $\leq 1.58 \mathrm{~L} \mathrm{~s}^{-1}$ before storage in $1000 \mathrm{~L}$ reservoir tanks. During pumping to the drill head the treated seawater was passed through a second UV light sterilization system (Weisenberger et al., 2019). Although great efforts were made to avoid contamination during drilling, a few applications of Florigel attapulgite mud were employed to secure borehole stability. After retrieval of the original HQ casing ( $88.9 \mathrm{~mm} \mathrm{OD}$ ), downhole logging of the borehole was undertaken by the ICDP Operational Support Group (Jackson et al., 2019; Weisenberger et al., 2019). The T-6061 anodized extruded aluminium NQ (69 mm OD) tubes that form the casing of the observatory were then were lowered to a landing depth of $181.25 \mathrm{~m}$ and hung in the borehole (Fig. 3c). A custom shoe was designed with a conical 
Table 1. List of depth intervals for each incubation experiment, and the corresponding temperatures measured in the 1979 borehole (SE01) in 2017 before the initiation of drilling.

\begin{tabular}{lrr}
\hline $\begin{array}{l}\text { Incubation } \\
\text { experiment }\end{array}$ & $\begin{array}{r}\text { Perforated casing } \\
\text { interval (m b.s.) }\end{array}$ & $\begin{array}{r}\text { Temperature } \\
\left({ }^{\circ} \mathrm{C}\right)\end{array}$ \\
\hline no. 1 & $37.01-38.63$ & 41 \\
no. 2 & $62.74-63.96$ & 96 \\
no. 3 & $106.11-107.33$ & 124 \\
no. 4 & $135.03-136.25$ & 101 \\
no. 5 & $160.48-161.70$ & 61 \\
\hline
\end{tabular}

shape to prevent infill of residual tephra and drilling debris during installation (Fig. 2d).

The 50 threaded NQ aluminium pipes that comprise the casing have an OD of $69 \mathrm{~mm}$ (2 3/4 in.), a $6.35 \mathrm{~mm}(0.25 \mathrm{in}$.) wall thickness and a $57 \mathrm{~mm}(21 / 4 \mathrm{in}$.) inner diameter. These occur in three lengths, $3.45,3.60$ and $3.75 \mathrm{~m}$, due to sourcing constraints encountered by the provider (Arconic Energy Systems, 7211 Spring Cypress Road, Spring, Texas 77379, USA). Five of the tubes are perforated (Figs. 2e, 4a). They have a pattern of five $6.35 \mathrm{~mm}$ diameter $(1 / 4 \mathrm{in}$.) holes, spaced equally in $72^{\circ}$ angular increments, on 29 equally spaced cross sections that extend over $1.21 \mathrm{~m}(4 \mathrm{ft})$ centred in the mid-section of each pipe (Fig. 4a). The perforated sections are placed at 37.01-38.63, 62.74-63.96, 106.11$107.33,135.03-136.25$, and $160.48-161.70$ m.b.s. at the sites of the incubation experiments (Fig. 1b; Table 1).

The casing is designed to hang freely within the open walls of the SE-02b borehole. It is assembled with a proprietary thread design developed by Arconic Energy Systems, tailored to meet the requirements for the casing size and application loads. The threaded flush joints were wrapped with Teflon $^{\mathrm{TM}}$ tape and wrenched together by hand. The Teflon ${ }^{\mathrm{TM}}$ tape concentrates a small amount of organic polytetrafluoroethylene (PTFE) compound at the joint. Paste lubricants were not used, since they could have been smeared along casing surfaces, potentially contaminating the observatory.

At the top of the borehole, the aluminium casing hanger attaches to the uppermost section of aluminium pipe (Fig. 2b). The hanger has a shoulder that is larger in diameter than the internal landing shoulder on the steel wellhead. An elastomer O-ring centres the aluminium casing hanger in the bore of the steel wellhead. A Teflon ${ }^{\mathrm{TM}}$ shim is installed between the aluminium casing hanger and the steel landing shoulder to prevent corrosion of the aluminium. Polyvinyl chloride (PVC) centralizer tubes are installed between the aluminium casing and the HWT conductor casing to several metres depth also to minimize corrosion (Fig. 2b, c). A custom wellhead flange and hinged cover holds the Vectran ${ }^{\mathrm{TM}}$ rope with the five incubation experiments, which are suspended in the centre of the perforated aluminium casing segments (Fig. 2c). The flange cover is installed $0.21 \mathrm{~m}$ above the reference ground level. The hinged cover prevents ingress of environmental contaminants, such as rainwater, and is secured with hex cap screws (Fig. 2c). The wellhead can easily be opened to retrieve the incubators during subsequent observatory experiments or data acquisition retrieval operations.

\section{Incubation experiments}

The Vectran ${ }^{\mathrm{TM}}$ rope is currently equipped with 40 perforated incubation polyether ether ketone chambers or PEEKins (Fig. 3) designed to investigate chemical, mineral and microbial alteration over an expected 2-year period, from September 2017 to summer 2019. Each PEEKin has an outer diameter of $18 \mathrm{~mm}$ and an inner diameter of $14 \mathrm{~mm}$. The perforations encourage the flow of in situ fluids and microbes into the chambers. Each PEEKin is attached with PEEK cable ties to an $8 \mathrm{~mm}$ diameter Vectran ${ }^{\mathrm{TM}}$ rope hung from the borehole wellhead. The PEEKins are deployed as packages of eight $(4 \times 2)$ to ensure replicates at each of the five perforated segment depths (38, 64, 108, 137 and 162 m.b.s.). A HOBO temperature logger monitors in situ temperature every $30 \mathrm{~min}$ at each depth. Artificial and sterile tephra, melted and quenched from Surtsey lava flows and separate packages of olivine crystals with compositions similar to those of Surtsey basalt (Fo $90,90 \%$ forsterite, $\mathrm{Mg}_{2} \mathrm{SiO}_{4} ; 10 \%$ fayalite, $\mathrm{Fe}_{2} \mathrm{SiO}_{4}$; Jakobsson and Moore, 1986), are used as substrates in the current PEEKin chambers. The samples and data will be collected from the observatory in summer 2019.

Recharge of the hydrothermal system at Surtsey is thought to occur through the inflow of cool seawater in porous, poorly consolidated tuff within the deeper zones of the submarine deposits; heating occurs as the water percolates upwards through the higher temperature rocks of the geothermal reservoir (Jakobsson and Moore, 1982, 1986; Ólafsson and Jakobsson, 2009). Pronounced deviations in several geophysical $\operatorname{logs}$ at $143-150$ m.b.s. in the SE-02b borehole confirm this inflow zone, where cooler water of higher salinity enters the borehole (Jackson et al., 2019). Vertical convection could initiate within the subsurface observatory but, based on the small casing diameter and temperature gradients, the flow rate would not strongly influence the alteration of the granules over the 2-year incubation periods.

Analytical investigations will evaluate rates of glass and mineral alteration, identify pioneering microorganisms, community dynamics and stability, and, potentially, provide pristine textural biosignatures of microbe-mineral interactions. The samples will be further analysed in terms of microbial genomics, including (1) community profiling by high throughput sequencing of prokaryotic $16 \mathrm{~S}$ ribosomal gene amplicons libraries, (2) shotgun sequencing of genomic DNA, and (3) quantification of key functional genes, such as $16 \mathrm{~S}$ rRNA, $m c r A$ and $d s r B$. Atomic force microscopy combined with vertical scanning interferometry (AFM-VSI) as well as synchrotron $\mathrm{X}$-ray microdiffraction studies will be 


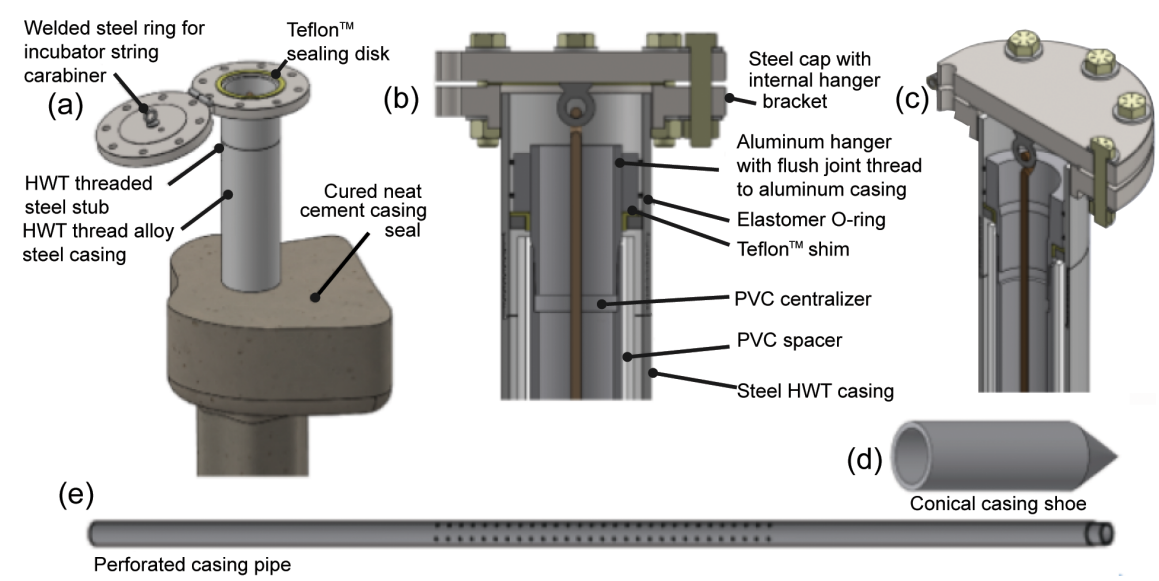

Figure 2. Borehole components of the Surtsey subsurface observatory. (a) HWT $(11.43 \mathrm{~cm}$ outer diameter) steel casing surrounds the aluminium casing to 9.54 m.b.s.; (b, c) components of the wellhead. (d) Conical NQ (69 mm OD) aluminium casing shoe, $25.4 \mathrm{~cm}$ (10 in.) in length. (e) Perforated NQ aluminium casing pipe, $3.66 \mathrm{~m}(12 \mathrm{ft})$ in length.

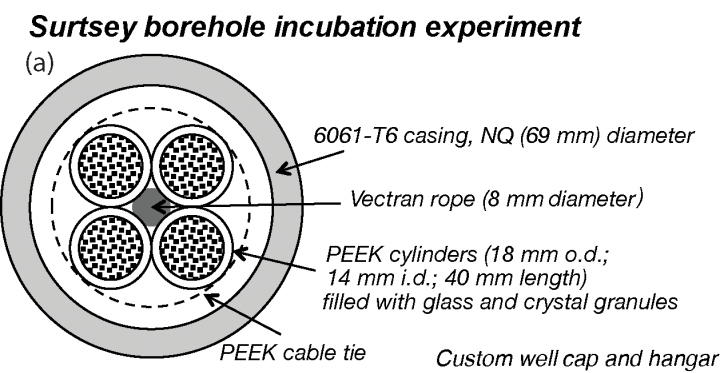

(b)

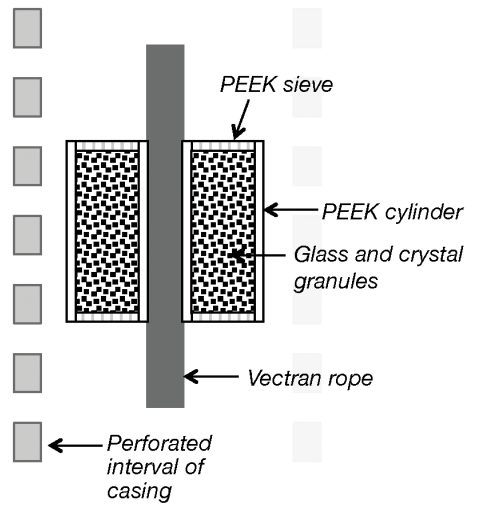

(c)

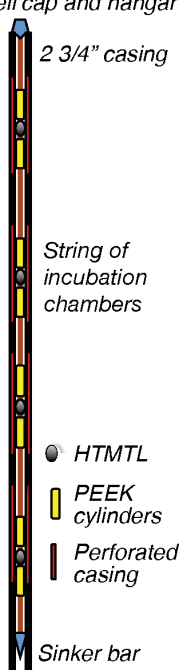

Figure 3. Design of the PEEK incubation chambers (PEEKins) and subsurface observatory in ICDP borehole 5059-1-C (SE-02b). (a) Schematic top view of the PEEKin as it is deployed in the borehole; (b) schematic side view of the PEEKin at intervals where the casing is perforated. (c) Sketch of the downhole observatory, which comprises an NQ anodized aluminium casing with five perforated sections, an inner Vectran ${ }^{\mathrm{TM}}$ rope hung from the wellhead with a sinker bar attached at its lower end and five incubation experiments placed at the perforated sections (Table 1).

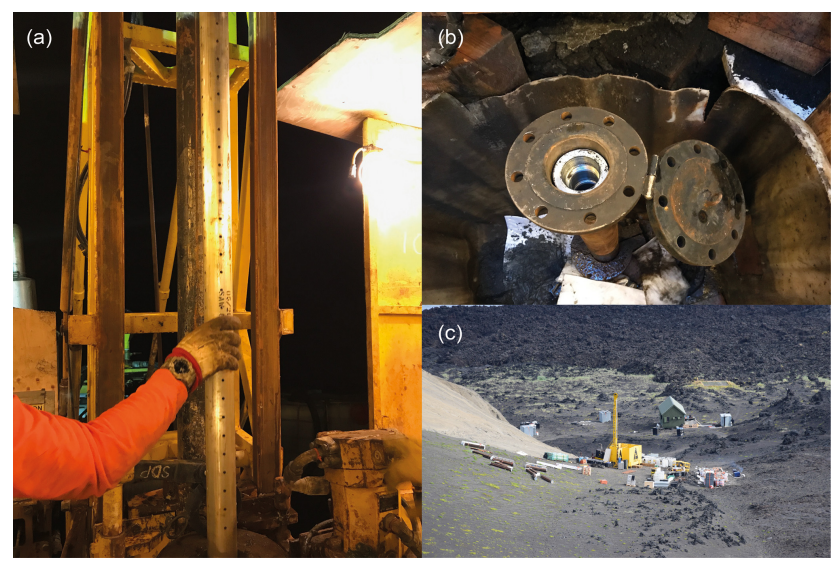

Figure 4. Photographs of drilling operations illustrating components of the borehole observatory. (a) Perforated casing interval as it is lowered into the borehole; (b) the open wellhead of the observatory. (c) Drill site and operations on Surtsey volcano. Photo credits: (a) Andreas Türke, (b) Stephen Cole and (c) Beau Marshall.

performed on the glass and olivine samples retrieved from the observatory.

\section{Outlook and perspectives}

The Surtsey subsurface observatory and its current experiments provide an unprecedented opportunity to study very young submarine basalt without the need for expensive and risky deep ocean operations. The current iteration of experiments and instruments deployed in the observatory will be retrieved in summer 2019. The observatory will be open to a broad scientific community from summer 2019 onwards, with priority granted to the SUSTAIN team members during the 4 years following the current experiment. The long-term management of the Surtsey subsurface observatory occurs 
through the commitment of the Surtsey Research Society. The borehole observatory is planned to remain operational and open for research for many decades. Information on access to the observatory and application procedures for future research projects is listed on the webpage of the Surtsey Research Society (http://www.surtsey.is).

Data availability. The article is a technical description of the Surtsey Subsurface Observatory. Initial data are expected in autumn 2019 , so there is no data repository at present. Information on access to the observatory and application procedures for future research projects is listed on the webpage of the Surtsey Research Society (http://www.surtsey.is).

Author contributions. MDJ and MTG led the drilling project. $\mathrm{BM}$ was the drilling operation supervisor. AT, WB, W-AK, and SLJ designed the components of the incubation chambers. BG, MDJ, $\mathrm{BM}$, and SLJ designed the components of the borehole casing. AT and MDJ wrote the article and created the figures with the assistance of SLJ, BG, WB, W-AK, and MTG.

Competing interests. The authors declare that they have no conflict of interest.

Disclaimer. Any use of trade, firm, or product names is for descriptive purposes only.

Acknowledgements. We thank all members of the SUSTAIN onsite and science teams and the Surtsey Research Society for their contributions to the drilling project. Bernd Zimanowski, at the University of Würzburg, produced the sterile basaltic glass for the current in situ experiments. The SUSTAIN project was funded by the International Continental Scientific Drilling Program (ICDP; led by Marie D. Jackson), the Icelandic Science Fund, ICF-RANNÍS (the IceSUSTAIN consortium led by Magnús T. Guðmundsson), the Bergen Research Foundation and K. G. Jebsen Centre for Deep Sea Research at the University of Bergen, Norway (led by Steffen Leth Jørgensen), the German Research Foundation (DFG; led by Wolfgang Bach and Bernd Zimanowski), and DiSTAR, University of Naples, Federico II, Italy (led by Piergiulio Cappelletti). The University of Utah, USA (Marie D. Jackson) and the two Icelandic power companies, Reykjavík Energy and Landsvirkjun, contributed additional funds. Anonymous reviewers made valuable improvements to the report.

Review statement. This paper was edited by Ulrich Harms and reviewed by two anonymous referees.

\section{References}

Bach, W.: Some compositional and kinetic controls on the bioenergetic landscapes in oceanic basement, Front. Microbiol., 7, 107, https://doi.org/10.3389/fmicb.2016.00107, 2016.

Baldursson, S. and Ingadóttir, Á.: Nomination of Surtsey for the UNESCO World Heritage List, Icelandic Institute of Natural History, Reykjavik, 2007.

Baquiran, J. P. M., Ramírez, G. A., Haddad, A. G., Toner, B. M., Hulme, S., Wheat, C. G., Edwards, K. J., and Orcutt, B. N.: Temperature and redox effect on mineral colonization in Juan deFuca Ridge Flank subsurface crustal fluids, Front. Microbiol., 7, 396, https://doi.org/10.3389/fmicb.2016.00396, 2016.

Edwards, K. J., Wheat, C. G., Orcutt, B., Hulme, S., Becker, K., Jannasch, H., Haddad, A., Pettigrew, T., and Bach, W.: Design and deployment of borehole observatories and experiments during IODP Expedition 336, Mid-Atlantic Ridge flank at North Pond. Integrated Ocean Drilling Program. Proceedings, Expedition Reports, 336, 109-109, 2012.

Jackson, M. D., Gudmundsson, M. T., Bach, W., Cappelletti, P., Coleman, N. J., Ivarsson, M., Jónasson, K., Jørgensen, S. L., Marteinsson, V., McPhie, J., Moore, J. G., Nielson, D., Rhodes, J. M., Rispoli, C., Schiffman, P., Stefánsson, A., Türke, A., Vanorio, T., Weisenberger, T. B., White, J. D. L., Zierenberg, R., and Zimanowski, B.: Time-lapse characterization of hydrothermal seawater and microbial interactions with basaltic tephra at Surtsey Volcano, Sci. Dril., 20, 51-58, https://doi.org/10.5194/sd-20-51-2015, 2015.

Jackson, M. D., Gudmundsson, M. T., Weisenberger, T. B., Rhodes, J. M., Stefánsson, A., Kleine, B. I., Lippert, P. C., Marquardt, J. M., Reynolds, H. I., Kück, J., Marteinsson, V. T., Vannier, P., Bach, W., Barich, A., Bergsten, P., Bryce, J. G., Cappelletti, P., Couper, S., Fahnestock, M. F., Gorny, C. F., Grimaldi, C., Groh, M., Gudmundsson, Á, Gunnlaugsson, Á. T., Hamlin, C., Högnadóttir, Th., Jónasson, K., Jónsson, S. S., Jørgensen, S. L., Klonowski, A. M., Marshall, B., Massey, E., McPhie, J., Moore, J. G., Ólafsson, E. S., Onstag, S. L., Perez, V., Prause, S., Snorrason, S. P., Türke, A., White, J. D. L., and Zimanowski, B.: SUSTAIN drilling at Surtsey volcano, Iceland, tracks hydrothermal and microbiological interactions in basalt 50 years after eruption: Sci. Drilling, in press, 2019.

Jakobsson, S. P. and Moore, J. G.: The Surtsey research drilling project of 1979, Surtsey Research, 9, 76-93, 1982.

Jakobsson, S. P. and Moore, J. G.: Hydrothermal minerals and alteration rates at Surtsey volcano, Iceland, Geol. Soc. Am. Bul., 97, 648-659, 1986.

Jakobsson, S. P., Thors, K., Vésteinsson, Á. T., and Ásbjörnsdóttir, L.: Some aspects of the seafloor morphology at Surtsey volcano: The new multibeam bathymetric survey of 2007, Surtsey Research, 12, 9-20, 2009.

Jørgensen, S. L. and Zhao, R.: Microbial inventory of deeply buried oceanic crust from a young ridge flank, Front. Microbiol., 7, 820, https://doi.org/10.3389/fmicb.2016.00396, 2016.

Lever, M. A., Rouxel, O., Alt, J. C., Shimizu, N., Ono, S., Coggon, R. M., Shanks W. C., Lepham, L., Elvert, M., Prieto-Mollar, X., Hinrichs, K. U., Inagaki, F., and Teske, A.: Evidence for microbial carbon and sulfur cycling in deeply buried ridge flank basalt, Science, 339, 1305-1308, 2013. 
Lysnes, K., Thorseth, I. H., Steinsbu, B. O., Øvreås, L., Torsvik, T., and Pedersen, R. B.: Microbial community diversity in seafloor basalt from the Arctic spreading ridges, FEMS Microbiol. Ecol., 50, 213-230, 2004.

Marteinsson, V., Klonowski, A., Reynisson, E., Vannier, P., Sigurdsson, B. D., and Ólafsson, M.: Microbial colonization in diverse surface soil types in Surtsey and diversity analysis of its subsurface microbiota, Biogeosciences, 12, 1191-1203, https://doi.org/10.5194/bg-12-1191-2015, 2015.

Ólafsson, M. and Jakobsson, S. P.: Chemical composition of hydrothermal water and water-rock interactions on Surtsey volcanic island: A preliminary report, Surtsey Research, 12, 29-38, 2009.

Orcutt, B. N., Bach, W., Becker, K., Fisher, A. T., Hentscher, M., Toner, B. M., Wheat, G., and Edwards, K. J.: Colonization of subsurface microbial observatories deployed in young ocean crust, The ISME journal, 5, 692, https://doi.org/10.1038/ismej.2010.157, 2011.

Takai, K., Nakamura, K., Toki, T., Tsunogai, U., Miyazaki, M., Miyazaki, J., Hirayama, H., Nakagawa, S., Nunoura, T., and Horikoshi, K.: Cell proliferation at $122^{\circ} \mathrm{C}$ and isotopically heavy $\mathrm{CH}_{4}$ production by a hyperthermophilic methanogen under highpressure cultivation, National Academy of Sciences Proceedings, 105, 10949-10954, 2008.
Thors, K. and Jakobsson, S. P.: Two seismic reflection profiles from the vicinity of Surtsey, Iceland, Surtsey Res. Progr. Rep., 9, 149$151,1982$.

Weisenberger, T. B., Gudmundsson, M. T., Jackson, M. D., Gorny, C. F., Türke, A., Kleine, B. I., Marshall, B., Jørgensen, S. L., Marteinsson, V. T., Stefánsson, A., White, J. D. L., Barich, A., Bergsten, P., Bryce, J. G., Couper, S., Fahnestock, M. F., Franzson, H., Grimaldi, C., Groh, M., Guðmundsson, Á., Gunnlaugsson, Á. T., Hamlin, C., Högnadóttir, Th., Jónasson, K., Jónsson, S., S., Klonowski, A., Kück, J., Magnússon, R. L., Massey, E., McPhie, J., Ólafsson, E. S., Onstad, S. L., Prause, S., Perez, V., Rhodes, J. M., and Snorrason, S. P.: Operational Report for the 2017 Surtsey Underwater volcanic System for Thermophiles, Alteration processes and INnovative Concretes (SUSTAIN) drilling project at Surtsey Volcano, Iceland, Geo Forschungs Zentrum report, 2019. 